Uniwersytet Śląski w Katowicach

Wydział Pedagogiki i Psychologiii

gienekszymikpoczta.onet.pl@onet.pl

ZuZANA KovÁČOvÁ

Faculty of Education Matej Bel University

Banská Bystrica, Slovak Republic

\title{
THEATRICAL AND QUASI - THEATRICAL FORMS IN FIRST STAGES OF SCHOOL EDUCATION In Poland
}

\author{
FORMY TEATRALNE I PARATEATRALNE \\ W POLONISTYCZNEJ EDUKACJI WCZESNOSZKOLNEJ \\ W Polsce
}

\begin{abstract}
The article makes the reader familiar with the most important and most interesting theatrical and quasi-theatrical forms, methods and techniques used in contemporary Polish schools. It begins with description of the simplest ones helping to develop the so-called 'living word culture' (e.g. narrating aloud, reading aloud, reciting, reading with roles assigned) Further, stage adaptations and modern forms of work utilising student-activating methods such as: drama games, inscenised trial, 'theatrical-literary workshop', and drama are described. After T. Samulczyk-Pawluk, the following contemporary theatrical forms are listed as well: self-made theatre, doll theatre, objects theatre, poetry theatre, pantomime, plastic theatre, theatre of propositions, small forms theatre.

The article contains a discussion of theatrical and quasi-theatrical forms in an early school education teacher's work. These can to a large extent catalyse a pupil's creative expression, which in turn allows him better to understand the text being discussed in class or play his part.
\end{abstract}




\section{STRESZCZENIE}

Artykuł przybliża czytelnikowi najważniejsze i najciekawsze formy, metody i techniki teatralne i parateatralne stosowane we współczesnej szkole w Polsce, od najprostszych, które kształcą tzw. kulturę żywego słowa (np. głośne opowiadanie [gawędę], głośne czytanie, recytację, czytanie z podziałem na role), przez inscenizacje, do nowoczesnych form pracy, z wykorzystaniem metod aktywizujących, takich jak: gry dramatyczne, sąd inscenizowany, „warsztaty teatralno-literackie” i drama. Wyróżniono również (za T. Samulczyk-Pawluk) następujące współczesne formy teatralne: teatr samorodny, teatr lalek, teatr przedmiotów, teatr poezji, pantomima, teatr plastyczny, teatr propozycji, teatr małych form.

$\mathrm{W}$ artykule wskazano jedną $\mathrm{z}$ najciekawszych form teatralnych stosowanych w szkołach słowackich - dramatyczne wychowanie.

Specyfikę artykułu stanowi omówienie zagadnienia związanego $\mathrm{z}$ rolą form teatralnych i parateatralnych w pracy nauczyciela edukacji wczesnoszkolnej, które mają duży wpływ na wyzwolenie ekspresji twórczej ucznia, co pozwala mu lepiej zrozumieć omawiany tekst literacki czy budować rolę.

KEYWORDS: theatrical and quasi-theatrical forms in Poland, early school education

SŁOWA KLUCzOWE: formy teatralne i parateatralne $w$ Polsce, polonistyczna edukacja wczesnoszkolna

\section{INTRODUCTION}

Theatrical action, understood as a method of education is contemporarily used mostly in Polish language and literature classes in higher grades and in linguistic-literary education classes in grades $1-3$. The most basic, and at the same time most traditional forms are the ones that help to shape the socalled 'living word culture'. These, according to Anna and Zdzisław Wiech, are: narrating aloud, reading aloud, reciting, reading with roles assigned (Wiechowie, 1971, p. 116 i next.). J. Awgulowa and W. Świętek (Awgulowa, Świętek, 1964; Awgulowa, 1979) it have written much about another popular form of theatrical action, namely stage adaptations. Their work provides us with concrete exemplificative material and tips regarding methodology that still remain surprisingly up-to-date. 


\section{STAGING}

They understand stage adaptation as a form of reading exercise, but they also understand it in a broader way - exercise in acting (in the meaning of 'performing action'), experiencing, and integrating into a group. Thus, they claim, staging meets the "requirement of satisfying a child's natural longing for movement and practical action" (can be "a strong stimulus towards children's achieving better results in reading, aesthetic speech, and even correct writing" (Ibidem, p. 5). The researchers also point out that the work on stage adaptation is of an interdisciplinary nature - it merges content belonging to different school subjects: art, technical education, and physical education.

They treat stage adaptation as a method, a form of in-class work, e.g. in Polish classes, but also as a part of the upbringing process, e.g. when the adaptation is to be a part of a school celebration. In the former case they treat it as a typical in-class activity and provide for the possibility of introducing improvisation, while in the latter case they suggest a necessity of meticulous preparation of the material with pupils faithfully playing their parts accordingly to a previously prepared script, which can take place only after school. One is inclined to claim that modern didactics understands stage adaptation in a similar way. It is understood both as simply presenting previously memorised parts of the play and as improvising dialogues within the framework of a loose script (Samulczyk-Pawluk, 2005, p. 109-110).

\section{DRAMATIC GAMES}

Drama games in turn belong to more modern forms of work that can be situated among activating and problem-based methods, which are the most popular ones in contemporary school. This term is used to describe "expressive-mimetic actions among children and youth. The aim of the games is finding in participants those abilities that make them active and creative" (Ibidem, p. 110). The 'game' is not about imitating professional theatre, but facilitating the appearance of creative activity. A 'game' can be a short motoricvocal exercise, but also a longer performance. The condition for the existence of such a 'game' is the independence of the pupils in using means of their own design to approach a given problem. 
According to the author of the present paper, drama game as a form of intersemiotic translation, being a relatively simple, fun-based exercise, prepares participants to deliver longer theatrical utterances. It teaches body eloquence and prepares for a skillful use of onstage space. Having carefully studied a literary text, attempted at defining characters' traits of personality, and understood the reasons behind their actions, the pupil is able to present how the characters might act and a possible conversation that might pass between them (Szymik, 1992, p. 54).

An author particularly well-versed in the subject, S. Rzęsikowski proposes using the following drama games accordingly to the pupils' age: grade 0 - pantomime, grades 1 and 2 - symulations of actions typical for school environment, grade 3 - stage adaptations of fairy tales, grade 4 - drama games based on poetry, higher grades - drama L. Rybotycka in turn summarises pedagogic values of drama games as follows: "Independence in thinking, acting, and shaping one's attitudes is a feature of persons mature and creative. Acquiring these values is a matter of upbringing. Young children already, and then older ones, should be given conditions in which they can think, judge, search, solve, and act. For independent and creative behaviour is not a readymade value that one can take for granted provided one reaches certain age, but it is a result of training that needs to start in one's childhood" (Rybotycka, 1976, p. 23).

\section{COURT STAGED}

One of the more interesting methods used with children, that can be treated as a type of drama game or a type of stage adaptation is a staged trial, where pupils play the parts of defendants, prosecutors, attorneys, judges and witnesses, recreating the proceedings of a real life trial. This way they delve deeper into the meanings and problems present in the literary text being discussed. Such trial might be just fun, might turn into a constructive dicussion, might be only a staging or might reach deeper and constitute a creative approach to a given problem. However, its aim is always to make the participants aware of a number of issues in the literary text which are difficult to notice or understand at the first sight (Samulczyk-Pawluk, 2005, p. 108). 


\section{„THEATRICAL-LITERARY WORKSHOP”}

Another interesting idea for activating young people is the "theatricalliterary workshop" (Latoch-Zielińska, 2003, p. 47-62) proposed and described by M. Latoch-Zielińska and based upon the concepts put forth by Celestin Freinet. The participants transform literary texts into stage performance scripts and in the process analyse and interpret the texts, discovering their symbolism, compositional features, and hidden meanings. The editorial work takes place on a 'brainstorm' basis; ideas emerge from discussion and creative and communication-based activities, which often require pupils to leave their desks as they not only make them practise their writing, but also help to develop their imagination, creativity, expression and empathy.

\section{DRAMA EXAMPLE OF A PARATHEATRICAL FORM}

A very inspiring method these days is drama. It surely is an innovative method, opposing the traditional ones. The term itself comes from the Greek word 'drao' meaning 'I act, strive'. A drama theorist and practitioner, Krystyna Milczarek-Pankowska writes that this method is often, although wrongly, considered a type of drama game. "For the latter term (...) is too narrow and does not encompass the whole of the essence of the method under discussion" (Milczarek-Pankowska, 1986, p. 34). The basis for drama are two features innate to any human being, making them equipped with natural drama predispositions. These features are a tendency to mime and situational imagination. Drama games are essentially games, they come with specified rules and are means for achieving specified goals. Drama is a broader and deeper term, derived from Montaigne's thought, where a child ought not to repeat but re-act the lesson to be learnt. In methodology based on drama, spontaneously playing different parts is assumed to enable the student to remember and understand different, even the most difficult educational content. For the basis of knowledge acquisition is not reading or listening, but experiencing, acting, assuming roles.

The essence of drama was described by B. Way (Way, 1995, p. 17-25) in his famous book "The Role of Drama in Development", in which he proposed a connection between role-playing and the basic actions involved in the learning process. He claims that a participant in drama should act without a script, that he 
should not memorise his lines, but he should improvise. Thus a 'live' performance is created, where the participant draws from the power of his own imagination and creativity. The participant uses his gestures, body, and facial expressions to express everything he feels, observes and experiences. He gives his own ways of solving the problems touched upon in the didactic process (Chrząszcz, 2007, p. 18-19).

The difference between theatre and drama is that the essence of theatre is based upon the communication between the stage and the audience, while in drama these are the experiences of the performers themselves that count (Pruszkowska, 2006, p. 3-5). K. Pankowska writes that drama is not at all about artistic effect but about reaching a pedagogic goal. "Even though it relates to role-playing, drama is not acting" (Samulczyk-Pawluk, 2005, p. 113) - writes Pankowska. All children, regardless of acting skills, can participate. In drama there is no pondering over the role, no practice, no rehearsals - everything is improvised. Drama theorists, the author of the present paper included, list numerous techniques of educational and pedagogic influence one can exert on pupils basing on drama, such as: statue, expert's coat, freeze, living image, museum and others. They also specify methodologies of utilising them in specific educational situations (Szymik, 2011, p. 31-39).

Drama is an important method in early school education. Utilising various drama techniques (individual and group statues, improvised scenes, short pantomimes, a character's soliloquy (role play), in-character chats, and simple experiences, i.e. exercises developing sensitivity of the senses: hearing, sight, touch, and smell, can „enliven” the text through action.

Building individual statues on words (concepts) given by the teacher aims at expressing the associations that are linked to these terms by means of proper emotional positions. These exercises are a perfect way to enrich pupils' vocabulary, as they have to pay attention to the way their arms and legs are arranged and their facial expressions. They describe their impressions and learn to talk about what they can see.

Group statues help the pupils to express the situations and meaningful events a character had been through. The statues also help pupils to develop their imagination, shape their sensitivity, and evoke emotions. Describing the statues makes the pupils verbalise their experiences and enrich their active vocabulary. 
Improvised scenes allow pupils to entrench their knowledge. In this manner it is easier for them to remember characters and their problems, i.e. the very content of the lesson.

Pantomime étude is a motoric form of working with an imagined object (e.g. playing with a ball). This technique helps to develop body language, aids in concentration and facilitates playing one's part.

Role play puts the participant in a completely new situation. The pupil becomes a literary character and assumes their way of thinking, uses his empathy to feel for them, thus creating an emotional bond between himself and the character. This drama technique makes the interpretation of the text deeper through the pupil's being personally engaged, having to show his knowledge of the piece being analysed, and create their own utterance based on a given text.

Conversation is the easiest way to be in character. This technique enables a deeper understanding of given character's experiences and behaviours. It also helps to practise language skills.

Simple experiences (Machulska, 1992, p. 6-7) are exercises developing auditory, visual, tactical, taste, and olfactory sensitivity (e.g. entering a dark room - listening carefully to sourrounding sounds).

\section{"AFTER SCHOOL THEATRE"}

The so-called 'after school theatre', as opposed to the above-discussed theatrical forms realised as immanent elements of obligatory classes in respective subjects, especially Polish, consists of all types of shows, programmes, or celebrations prepared by groups, day centers, and school libraries. These can be various forms of theatre. T. Samulczyk-Pawluk describes the following ones as the most interesting and attractive for young people:

Self-made theatre - spontaneous pupils' theatre based on adults-free play. It develops freely in children's minds, without a teacher's intervention. It requires no stage, costumes, or decorations. It is based on improvisation. The roles are interchangeable here - members of the audience can spontaneously become actors and the other way round. Anyone can be a director. This form of theatre was introduced in Polish scouting by Aleksander Kamiński. 
Doll theatre - theatre merging dramatic traits with plastic arts and technical activities. It encompasses such stages of creating the show as: designing, making, cutting out, and breathing life into the dolls. This process integrates the participants to an unusual degree. Doll theatre creates a world in miniature and enables the child to discover the outside world through it. The most important part here is played by the doll, which, being something in between an object and a human being, is always a kind of metaphor. Doll theatre is meant mostly for younger children, as it is in line with their spontaneous games in which objects-made-alive play an important part. Among great admirers of doll theater one could mention for instance Jan Sztaudynger.

Object theatre - for some a subgenre of doll theatre, based on a group of objects that, as the actor and the director will it, create their own language, which they use to communicate with the audience. Object theatre teaches children aesthetic sensibility and appreciating the importance of detail. It also engages their imagination. Andersen's tales provide readymade scripts for this type of shows.

Poetry theatre - in this form Urszula Wierzbicka perceives creative inspiration and uniqueness of a genre subjected to - to quote - "permanent evolution - change being its formal distinctive feature. Visual arts, lighting, elements of metaphorical poetic stage decorations, music, all appear on equal terms (...) with the word" (Wierzbicka, 1979, p. 10). Because of the merger of elements taken from different arts, this kind of theatre is described as syncretic. Its dydactic value resides in bringing young people, to whom especially it is addressed, closer to both poetry in particular and art in general. Thus it achieves a correlation of effects in the field of aesthetic education. It is a good thing when poetry theater is not based on readymade published scripts, but arises out of inspiration, among creative discussions and reflections of the readers-participants creating their own unique poetic collage.

Pantomime - in other words theatre of movement, gives up word as a medium, while concentrating on gesture, facial expression and choreography. The essence of this form is the conviction that every human feeling, thought, and state of mind can be expressed with gestures. It is not only the actor, but also the spectator who needs to be creative here. The reason for this is the fact 
that theatre of movement is the most conventional of theatre types, where imagination and ability to read signs and symbols plays the greatest part.

Plastic theatre - another innovative theatrical form, which gives up word in favour of searching for new means of expression. It creates shows at the border of theatre and kinetic art, happening, ritual, sometimes circus, very often overthrowing norms and commonly accepted aesthetic values. A mixture of arts and complete creative freedom are par for the course here. This form is governed by accident, illogicality, lack of plot and infiniteness. The plastic material, human body included, remains the basic one.

Theatre of propositions - It is, according to Wierzbicka, "a dialogue between the stage and the audience on socially weighty issues" (Ibidem, p. 15). The element of discussion is crucial here, as the show serves as a pretext for showing problems that are important and complicated and evoke contradictory opinions onstage. Either scripts created by the participants or classics, re-read in a modern way, are utilised to achieve this aim. Directing the show and the choice of texts should in their entirety be left to the pupils.

Small forms theatre - this genre can be singled out as the most representative for the whole of school theatre (Ibidem, p. 18 i next.). It consists in organising a show mixing various types of artistic material: poems, songs, monologues, dialogues, interviews, musical pieces, dance, pantomime. Word is not dominant here, all the elements of the show function on a parallell basis. One, thought through, concept allows to merge the works of various groups within a school, such as: dance, recitation, plastic arts or music, so that they can work together for a common result. What really counts is the idea around which the whole action is built and using shortcuts, symbols, metaphors instead of a traditional plot structure.

\section{SUMMARY}

The forms described above do not, of course, constitute a comprehensive or a complete set. One could add to them, just to mention some, 'theatre at a table', mini-shows, 'theatres in live environment', cabaret, word - music stages and others. In contemporary schools it is often the case that creative students, in cooperation with their teacher, merge different forms of theatre in one show, thus creating original, truly unique shows. 


\section{DRAMA LESSON SCENARIO}

The following part of the article contains a lesson scenario that prescribes for the teachers and the pupils to utilise various drama and dramatic education techniques. The scenario is structured so that it provides pupils with occasions to be emotionally involved as well as have their activity, imagination, and logical thinking spurred.

Lesson subject: Poetic description of rain in the poem Summer downpour.

Context-based dimension: an attempt at presenting the content of the poem by means of sound effects.

Universal dimension: similarity of sound and poetic effects

Personality-based dimension: an attempt at answering the question: am I sensitive to music?; myself and nature.

Drama techniques and exercises: pupils' roles: exercises developing auditory sensitivity (illustrating the poem with percussions), drawing, pantomime étude; teacher's role: reciting the poem.

\section{Lesson plan:}

1. Introduction - presentation and discussion of illustrations depicting summer rain.

2. Listening to the teacher reciting "Summer downpour" by S. Szuchowa.

\section{S. Szuchowa: Summer downpour}

Very fine

Light and silent

Over branches of beeches

And over leaves of birches

Upon woods far and wide

Rain whispered by.

And then in but an instance

wind bent the treetops mighty

and lo! the trees are swooshing!

A downpour! A terrible one!

And suddenly... All's silent.

The woods shining and breathing. 
There's a window of blue sky

over the nearest pine's top.

Birds singing as if at dawn...

Now the downpour is over.

3. Drama exercises - pantomime étude

Teacher asks pupils the following question: how will you react in the situation I describe?

*You are alone in the woods. Suddenly wind begins to blow. Trees' boughs are bent. A terrible downpour starts. How will you react?

4. Dividing the poem into three parts.

Pointing to correct intonation while reading the poem.

5. Reading the poem aloud.

6. An attempt at explaining the poetic descriptions. Light and silent / Over branches of beeches / And over leaves of birches / Upon woods far and wide / Rain whispered by./ and lo! the trees are swooshing! / There's a window of blue sky / over the nearest pine's top.

7. Drama exercises - interpreting the poem with percussions.

a) The class is divided into two groups. One group is reading the poem aloud and the other one is illustrating it playing the percussions. Pupils illustrate "Very fine" with triangles, rattles, metallophones, and add drums, hi-hats and clappers when the downpour starts. At the end the instruments are muted.

b) Pupils are divided into two groups. One group is interpreting summer downpour with instruments, and the other one with body moves.

8. Homework suggestion: Create a picture illustrating a fragment of the poem. 


\section{References}

Awgulowa, J. (1979). Dziecko widzem i aktorem. Inscenizacje dla klas przedszkolnych, świetlic, domów dziecka, Warszawa: Wydawnictwa Szkolne i Pedagogiczne. ISBN 8302006785.

Awgulowa, J., Świętek, W. (1964). Inscenizacje w klasach I-IV, Warszawa: Wydawnictwa Szkolne i Pedagogiczne.

Chrząszcz, K. (2007). Istota i funkcja dramy, „Wychowanie na co dzień”, nr 12. ISSN 1230-7785.

Latoch-Zielińska, M. (2003). Warsztaty teatralno-literackie $w$ praktyce szkolnej, [in:] B. Myrdzik (red.), Od teatru żaków do Internetu, Lublin: Wyd. UMCS. ISBN 8322721854 .

Machulska, H. (1992). Środki teatralne w procesie nauczania $i$ wychowania (3), „Drama”, z. 3.

Milczarek-Pankowska, K. (1986). Drama na lekcjach języka polskiego, „Polonistyka”, nr 1 (231). ISSN 0551-3707.

Pruszkowska, A. (2006). Drama i teatr - czy to krewniacy?, „Drama”, z. 51.

Rybotycka L., Gry dramatyczne. Teatr młodzieży, Wydawnictwa Szkolne i Pedagogiczne, Warszawa 1976. ISBN 8370100864.

Samulczyk-Pawluk, T. (2005). Edukacja teatralna w szkole podstawowej, Kraków: Oficyna Wydawnicza „Impuls”. ISBN 9788373087309.

Szymik, E. (2011). Drama w nauczaniu języka polskiego. Kraków: Oficyna Wydawnicza „Impuls”. ISBN 9788375876000.

Szymik, E. (1992 marzec). Gry dramatyczne forma kształcenia sprawności językowej uczniów, „Język Polski w Szkole dla klas IV-VIII”, z. 4.

Way, B. (1995). Drama w wychowaniu dzieci i młodzieży, Warszawa: Wydawnictwa Szkolne i Pedagogiczne. ISBN 8302057991.

Wiechowie, Z.A. (1971). Poradnik dla wychowawców świetlic szkolnych, Warszawa: Wydawnictwa Szkolne i Pedagogiczne.

Wierzbicka, U. (1979). Szkolny teatr małych form w moim doświadczeniu pedagogicznym, Warszawa: Wydawnictwa Szkolne i Pedagogiczne. ISBN 8302000698. 